University of Nebraska - Lincoln

DigitalCommons@University of Nebraska - Lincoln

Growth of Forage Legumes and Grasses in Acidic Soil Amended with Flue Gas Desulfurization Products

\author{
R. B. Clark \\ USDA-ARS
}

V. C. Baligar

USDA-ARS-Alternate Crops and Systems Laboratory, vbaligar@asrr.arsusda.gov

Follow this and additional works at: https://digitalcommons.unl.edu/usdaarsfacpub

Part of the Agricultural Science Commons

Clark, R. B. and Baligar, V. C., "Growth of Forage Legumes and Grasses in Acidic Soil Amended with Flue Gas Desulfurization Products" (2003). Publications from USDA-ARS / UNL Faculty. 514.

https://digitalcommons.unl.edu/usdaarsfacpub/514

This Article is brought to you for free and open access by the U.S. Department of Agriculture: Agricultural Research Service, Lincoln, Nebraska at DigitalCommons@University of Nebraska - Lincoln. It has been accepted for inclusion in Publications from USDA-ARS / UNL Faculty by an authorized administrator of DigitalCommons@University of Nebraska - Lincoln. 


\title{
Growth of Forage Legumes and Grasses in Acidic Soil Amended with Flue Gas Desulfurization Products
}

\author{
R. B. Clark ${ }^{\#}$ and V. C. Baligar* \\ USDA-ARS-Alternate Crops and Systems Laboratory, Beltsville \\ Agricultural Research Center-West, Beltsville, Maryland, USA
}

\begin{abstract}
Large amounts of flue gas desulfurization products (FGDs) are produced when $\mathrm{SO}_{2}$ emissions are trapped in the coal burning process for generation of electricity. FGDs are normally discarded instead of being reused, and reuse on soils could be important in overall management of these products. Glasshouse experiments were conducted to determine effects of various levels of three FGDs (a FGD gypsum, an oxidized FGD + Mg, and a stabilized FGD) and the control compounds $\mathrm{CaCO}_{3}$, $\mathrm{CaSO}_{3}$, and $\mathrm{CaSO}_{4}$ on growth of alfalfa (Medicago sativa), white clover (Trifolium repens), orchardgrass (Dactylis glomerata), tall fescue (Festuca arundinacea), switchgrass (Panicum virgatum), and eastern gamagrass (Tripsacum dactyloides) in acidic ( $\mathrm{pH} 4)$ soil (Typic
\end{abstract}

\footnotetext{
${ }^{\#}$ Formerly with USDA-ARS, now retired.

*Correspondence: V. C. Baligar, USDA-ARS-Alternate Crops and Systems Laboratory, Beltsville Agricultural Research Center-West, Beltsville, MD 20705, USA; E-mail: vbaligar@asrr.arsusda.gov.
} 
Hapludult). The FGDs enhanced growth of each plant species, with alfalfa, white clover, and tall fescue receiving greater increases than the other species, especially when grown in soil amended with FGD $+\mathrm{Mg}$. FGD gypsum did not often enhance growth unless high amounts were added. FGDs containing high $\mathrm{B}$ and low levels of $\mathrm{CaSO}_{3}$ were detrimental to growth. Overall, FGDs improved growth responses of these forage plants grown in an infertile low $\mathrm{pH}$ soil.

\section{INTRODUCTION}

Many coal combustion products (CCPs), especially flue gas desulfurization products (FGDs), are produced when coal is burned for generation of electricity. Generation of FGDs results by trapping sulfur dioxide $\left(\mathrm{SO}_{2}\right)$ from flue gases, which is accomplished by injecting $\mathrm{Ca}$ based sorbents, particularly limestone, to form $\mathrm{CaSO}_{3} / \mathrm{CaSO}_{4}$. Most FGDs as well as other CCPs are discarded into landfills, even though many could be reused. In the United States, a 1999 survey indicated that only $10 \%$ of FGDs were being reused in $1998 .{ }^{[1]}$ Uses of FGDs could be as an amendment to soils, especially acidic soils, for increasing soil $\mathrm{pH}$ to alleviate plant mineral toxicities [e.g., aluminum (Al) and manganese $(\mathrm{Mn})$ ] and deficiencies [e.g., calcium $(\mathrm{Ca})$, phosphorus $(\mathrm{P})$, and magnesium $(\mathrm{Mg})$; for providing a source of mineral nutrients to plants [e.g., Ca, sulfur (S), Mg, boron (B), zinc ( $\mathrm{Zn}$ ), and molybdenum (Mo)]; for improving soil water infiltration, water-holding capacity, and aggregation; for reducing soil crusting and erosion; for reducing $\mathrm{P}$ run-off from high-P surface soils into streams and estuaries; and for co-utilizing with organic/compost materials. ${ }^{[2-13]}$ Use of FGDs on land could be important in overall management of these products.

Information about FGD effects on plant growth needs to be evaluated if these products are to be reused on land. The FGDs formed are normally slurries consisting mainly of $\mathrm{CaSO}_{3}$, and other solid materials like fly ash, calcined lime $\left[\mathrm{CaO}\right.$ and $\left.\mathrm{Ca}(\mathrm{OH})_{2}\right]$, and/or additional limestone are commonly added to stabilize such products. Unreacted or added limestone and $\mathrm{CaO} / \mathrm{Ca}(\mathrm{OH})_{2}$ are alkalizing agents which can increase $\mathrm{pH}$ when mixed with soil. In some cases, $\mathrm{CaSO}_{3}$ is converted directly to $\mathrm{CaSO}_{4}\left(\mathrm{CaSO}_{4}\right.$ is used throughout the text for $\mathrm{CaSO}_{4} \cdot 2 \mathrm{H}_{2} \mathrm{O}$ and/or $\mathrm{CaSO}_{4} \cdot \frac{1}{2} \mathrm{H}_{2} \mathrm{O}$ ) through processes such as "forced oxidation" to form gypsum.

Information about the effects of FGDs on growth of plants is limited. In glasshouse studies, maize (Zea mays L.) was grown in acidic soil amended with various types of FGDs to determine their effects on growth and on soil $\mathrm{pH}$ 
and electrical conductivity (EC). ${ }^{[14,15]}$ In these studies, some FGDs were very effective in enhancing growth and improving soil $\mathrm{pH}$, while others were not. Plants grown in unamended soil consistently had relatively severe growth inhibitions, and these inhibitions were alleviated to some extent by applications of FGD. Of the FGDs tested, one particularly benefited plants at low levels of application, which was a FGD $+\mathrm{Mg}$ product. Another FGD decreased growth at application levels of less than 5\% (to convert percentage values in soil mixes to metric tons $\mathrm{ha}^{-1}$ multiply by 22) in soil mixes, but such growth inhibitions were overcome as level increased. Most FGDs (nonstabilized and stabilized) could be added only at low levels (1-3\%) in soil mixes, while oxidized FGDs (FGD gypsum) could be added at high levels $(50-75 \%)$ in soil mixes.

A FGD gypsum product increased coastal bermudagrass [Cynodon dactylon (L.) Pers.] yields over two years by 26 and 35\%, respectively, with 0.25 and 0.5 metric ton ha $^{-1}$ applications to soil. ${ }^{[16]}$ Addition of the FGD had no significant effects on soil $\mathrm{pH}$ although the highest level had slight acidifying effects at various soil depths. Alfalfa (Medicago sativa L.) grown over two years in acidic soil amended with a FGD gypsum product had yield increases of $14 \%$ over controls at the highest level (18 metric ton ha ${ }^{-1}$ ) added. ${ }^{[1]}$ Growth increases were attributed to decreased soil $\mathrm{Al}$ and not from increased acquisition of mineral nutrients. Citrus (Citrus spp.) grown in sandy soil with low extractable $\mathrm{Ca}$ at two locations had increased fruit yields, fruit soluble solids, and leaf Ca (one location) when FGD gypsum was applied at 2.24, but not 1.12, metric ton ha ${ }^{-1} \cdot{ }^{[18]}$ In a glasshouse study, Punshon et al. ${ }^{[19]}$ did not find enhanced growth when maize was grown in soil mixed with various levels of a FGD. However, maize, soybean [Glycine max (L.) Merr.], cotton (Gossypium hirsutum L.), and radish (Raphanus sativus L.) grown in mesocosms (tanks in the field) had enhanced growth when this same FGD was added to soil, and plant species differed in level of FGD required to produce maximum plant dry matter. ${ }^{[19]}$

Enhanced alfalfa (Medicago sativa L.) and tall fescue (Festuca arundinacea Schreb.) growth in glasshouse studies were noted when dry FGDs [fluidized bed combustion (FBC) products] were applied, and alfalfa produced greater yields than tall fescue. ${ }^{[20]}$ In field studies, a FBC $+\mathrm{Mg}$ product enhanced growth of alfalfa, but not maize. ${ }^{[21]}$

The objective of our studies was to determine effects of different levels of three FGDs added to acidic soil on growth of six forage species. These plants were also grown in acidic soil amended with different levels of the control compounds $\mathrm{CaCO}_{3}, \mathrm{CaSO}_{3}$, and $\mathrm{CaSO}_{4}$ for comparison to FGDs. The effects 
of added FGDs and control compounds on soil $\mathrm{pH}$ and EC have also been related to growth.

\section{MATERIALS AND METHODS}

An acidic Lily soil (fine loamy, siliceous, mesic, Typic Hapludult) was used, and some of its properties before addition of amendments were: $43.1 \%$ sand, $38.8 \%$ silt, and $18.2 \%$ clay; $4.70 \%$ organic matter; $4.48 \mathrm{pH}_{\mathrm{W}}$ (1 soil: 1

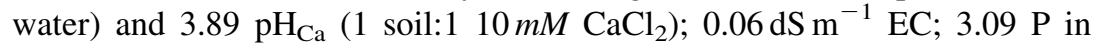
$\mathrm{mg} \mathrm{kg}^{-1}$ soil (Bray-1 extractable); $70.0 \mathrm{~S}, 69.5 \mathrm{~K}, 45.8 \mathrm{Ca}, 5.06 \mathrm{Mg}$, and 2.30 $\mathrm{Na}$ in $\mathrm{mg} \mathrm{kg}^{-1}$ soil $\left(1 \mathrm{M} \mathrm{NH}_{4}\right.$-acetate extractable $) ; 53.8 \mathrm{Fe}, 33.1 \mathrm{Mn}, 0.716 \mathrm{Zn}$, $0.125 \mathrm{Cu}$ in $\mathrm{mg} \mathrm{kg}^{-1}$ soil (5 $\mathrm{mM}$ DTPA extractable); $3.36 \mathrm{Al}$ in $\mathrm{cmol}_{\mathrm{c}} \mathrm{kg}^{-1}$ soil (1 $M \mathrm{KCl}$ extractable); 3.82 cation exchange capacity in $\mathrm{cmol}_{\mathrm{c}} \mathrm{kg}^{-1}$ soil; and $88.0 \% \mathrm{Al}$ saturation of cation exchange capacity.

Air-dried soil was passed through a $2 \mathrm{~mm}$ screen, mixed thoroughly with fertilizer ( $50 \mathrm{~N}$ as $\mathrm{NH}_{4} \mathrm{NO}_{3}$ and $143 \mathrm{P}_{\text {as }} \mathrm{KH}_{2} \mathrm{PO}_{4}$ in $\mathrm{mg} \mathrm{kg}^{-1}$ soil) and various levels of control compounds (chemical grade $\mathrm{CaCO}_{3}, \mathrm{CaSO}_{3}$, and $\mathrm{CaSO}_{4}$ ) or FGDs, and soil mixes placed in plastic containers $\left(1.0 \mathrm{~kg}\right.$ soil mix pot $\left.{ }^{-1}\right)$. See data tables for levels of each material added to soil mixes. Levels of control substances and FGDs added to soil were to achieve both growth enhancements and depressions as established in earlier studies (unpublished data). ${ }^{[14]}$ Levels of $\mathrm{CaSO}_{3}$ and FGD-28 (stabilized FGD) added to soil were similar as both of these materials had high $\mathrm{SO}_{3}-\mathrm{S}$, and levels of $\mathrm{CaSO}_{4}$ and FGD-22 (FGD gypsum) were similar as both of these materials had high $\mathrm{SO}_{4}-\mathrm{S}$. FGD-27 was a FGD + Mg product. Some selected properties of the FGDs are provided in Table 1.

The plant species used in the experiments were two legumes [alfalfa (Medicago sativa L. cv. 'Vernal') and white clover (Trifolium repens L. cv. 'Huia')], two cool-season grasses [orchardgrass (Dactylis glomerata L. cv. 'Wana') and tall fescue (Festuca arundinacea Schreb. cv. 'KY31')], and two warm-season grasses [switchgrass (Panicum virgatum L. cv. 'Cave-in-Rock') and eastern gamagrass (Tripsacum dactyloides L. cv. 'WW1459')]. Seeds of each plant species were surface-sterilized with 0.1 -strength $\mathrm{NaOCl}$ (household bleach) for $5 \mathrm{~min}$ and rinsed thoroughly with distilled water. Six to eight seeds were planted in each pot of moist soil, seedlings were allowed to establish, and thinned to three pot $^{-1}$ a few days after seedling emergence. Deionized water was added manually as needed to avoid splashing on stalks and leaves and to provide sufficient water for growth. Care was taken to avoid leaching from pots. Minor leaching occurred sometimes from some pots when plants did not grown well. Nevertheless, soil pH and EC values after amendment addition 
Table 1. Selected properties of FGDs used to amend acidic soil ${ }^{\mathrm{a}}$.

\begin{tabular}{llccc}
\hline Property & \multicolumn{1}{c}{ Unit } & FGD-22 & FGD-27 & FGD-28 \\
\hline pH (1 FGD:1 water) & & 8.91 & 9.53 & 8.68 \\
pH (1 FGD:2 water) & & 8.96 & 9.65 & 8.82 \\
EC (1 FGD:1 water) & $\mathrm{dS} \mathrm{m}^{-1}$ & 1.67 & 3.35 & 5.58 \\
EC (1 FGD:2 water) & $\mathrm{dS} \mathrm{m}^{-1}$ & 1.92 & 3.29 & 4.17 \\
$\mathrm{CCE}$ & $\%$ & 5.0 & 13.1 & 69.3 \\
$\mathrm{Chemical} \mathrm{element}^{\mathrm{b}}$ & $\%$ & & & \\
$\mathrm{~S}_{-} \mathrm{SO}_{3}$ & $\mathrm{~g} \mathrm{~kg}^{-1}$ & 0.8 & 1.0 & 25.9 \\
$\mathrm{~S}_{-} \mathrm{SO}_{4}$ & $\mathrm{~g} \mathrm{~kg}^{-1}$ & 216 & 176 & 200 \\
$\mathrm{Ca}$ & $\mathrm{g} \mathrm{kg}^{-1}$ & 238 & 209 & 509 \\
$\mathrm{Mg}$ & $\mathrm{g} \mathrm{kg}^{-1}$ & 0.23 & 22.7 & 24.4 \\
$\mathrm{~K}$ & $\mathrm{mg} \mathrm{kg}^{-1}$ & 32 & 165 & 88 \\
$\mathrm{P}$ & $\mathrm{mg} \mathrm{kg}^{-1}$ & 60.7 & $<0.03$ & 90.7 \\
$\mathrm{~B}$ & $\mathrm{mg} \mathrm{kg}^{-1}$ & $<0.02$ & 99.0 & 7.81 \\
\hline
\end{tabular}

${ }^{\text {a }}$ Additional properties of FGD-22 (BP-\#22)and FGD-27 (BP-\#27)are reported in Clark et al. ${ }^{[14]}$

${ }^{\mathrm{b}} \mathrm{CCE}=$ Calcium carbonate equivalency.

and equilibrium had similar values to soils after plant growth, thus, any minor leaching appeared to have no effect on soil $\mathrm{pH}$ and EC.

Plants were grown in a glasshouse $\left(25 \pm 3^{\circ} \mathrm{C}\right)$ using natural and artificial light to maintain the light period at $14 \mathrm{~h}$ and to provide extra light during cloudy days. Artificial light $\left(400-500 \mu \mathrm{mol} \mathrm{m}^{-2} \mathrm{~s}^{-1}\right.$ photo flux density at plant height) was provided by high-pressure $\mathrm{Na}$ lamps. Because of the large number of treatments and plant species, experiments were conducted over a period of time and each species was grown at least in two experiments, except alfalfa which was grown in only one experiment. Growth periods for each plant species were $82 \mathrm{~d}$ for alfalfa, $59 \mathrm{~d}$ for white clover, $55 \mathrm{~d}$ for orchardgrass, $54 \mathrm{~d}$ for tall fescue, $69 \mathrm{~d}$ for switchgrass, and $71 \mathrm{~d}$ for eastern gamagrass.

At harvest, shoots were severed $\sim 1 \mathrm{~cm}$ above the soil surface or $\sim 0.5 \mathrm{~cm}$ above the crown. Representative soil samples were collected from each pot for determination of soil $\mathrm{pH}_{\mathrm{Ca}}$ (1 soil:1 $10 \mathrm{mM} \mathrm{CaCl} \mathrm{Ca}_{2}$ ) and $\mathrm{EC}$ (1 soil:1 water). Soil with roots was placed on $2 \mathrm{~mm}$ screens and roots thoroughly washed free of adhering soil. Crowns were separated from root segments and shoots and crowns were dried separately at $60^{\circ} \mathrm{C}$, after which they were weighed for dry matter (DM). Roots from each pot were cut into $\sim 2 \mathrm{~cm}$ length segments, 
thoroughly mixed, and fresh weight subsamples $(5-10 \mathrm{~g})$ were collected for determination of root length (RL) using a Comair RL scanner (Commonwealth Aircraft Corp. Ltd., Melbourne, Australia ${ }^{a}$ ). Remaining roots and root subsamples for RL determinations were dried separately similar to shoots and weighed. Total shoot (shoots + crowns) and root DM were determined. Specific RL (SRL) was calculated as length of roots (m) per g root DM.

The experimental design was completely randomized blocks with four replications, except for alfalfa which had six replications. Least significance differences (LSD) at $P<0.05$ were used to evaluate differences among means. $^{[22]}$

\section{RESULTS}

\section{Soil $\mathrm{pH}_{\mathrm{Ca}}$ And EC}

Soil $\mathrm{pH}_{\mathrm{Ca}}$ and $\mathrm{EC}$ values were averaged over soils in which the various plant species were grown with added control compounds and FGDs (Table 2), since values were similar across similar treatments. Soil $\mathrm{pH}_{\mathrm{Ca}}$ (3.9 in unamended soil) increased as expected when soil was amended with $\mathrm{CaCO}_{3}$, and was $>5.5$ at the $0.5 \%$ level in the soil mixes. Increasing levels of $\mathrm{CaSO}_{3}$ or $\mathrm{CaSO}_{4}$ had little effect on soil $\mathrm{pH}_{\mathrm{Ca}}$. In fact, $\mathrm{CaSO}_{4}$ at $75 \%$ in soil mixes increased soil $\mathrm{pH}_{\mathrm{Ca}}$ by only $0.4-0.5$ units. FGD-22 increased soil $\mathrm{pH}_{\mathrm{Ca}}$ to $\sim 7$ at high levels of addition (75\%). Level of FGD-28 required to raise soil $\mathrm{pH}_{\mathrm{Ca}}$ to $\sim 5$ was $3 \%$, and level of FGD-27 required to raise soil $\mathrm{pH}_{\mathrm{Ca}}$ to $\sim 7$ was $10 \%$.

$\mathrm{CaCO}_{3}$ had essentially no effect on increasing soil EC, but both $\mathrm{CaSO}_{3}$ and $\mathrm{CaSO}_{4}$ did. Soil EC was $0.10 \mathrm{dS} \mathrm{m}^{-1}$ in unamended soil and increased to $1.05 \mathrm{dS} \mathrm{m}^{-1}$ with $5 \%$ added $\mathrm{CaSO}_{4}$ (10-fold increase), and soil EC remained relatively constant with additional 15-fold increases in level of $\mathrm{CaSO}_{4}$ added to soil. Soil EC consistently increased as level of $\mathrm{CaSO}_{3}$ increased. FGD-22 added to soil had similar effects on $\mathrm{EC}$ as $\mathrm{CaSO}_{4}$, in that $\mathrm{EC}$ remained relatively constant with successive incremental increases of FGD-22. On the other hand, both FGD-27 and FGD-28 increased soil EC consistently as their level increased in soil.

\footnotetext{
${ }^{\mathrm{a}}$ Mention of trade names or commercial products in this publication is solely for the purpose of providing specific information and does not imply recommendation or endorsement by the U.S. Department of Agriculture.
} 
Table 2. $\mathrm{pH}_{\mathrm{Ca}}$ and electrical conductivity (EC) values for acidic Lily soil after amendment with various levels of $\mathrm{CaCO}_{3}, \mathrm{CaSO}_{3}$, $\mathrm{CaSO}_{4}$, and three FGDs (means after growth of six plant species).

\begin{tabular}{|c|c|c|c|}
\hline Treatment & $\begin{array}{c}\text { Level } \\
(\% \text { in Soil) }\end{array}$ & $\mathrm{pH}_{\mathrm{Ca}}$ & $\mathrm{EC}\left(\mathrm{dS} \mathrm{m}^{-1}\right)$ \\
\hline Control & 0 & $3.93 \pm 0.08$ & $0.10 \pm 0.02$ \\
\hline \multirow[t]{3}{*}{$\mathrm{CaCO}_{3}$} & 0.125 & $4.46 \pm 0.08$ & $0.10 \pm 0.03$ \\
\hline & 0.25 & $4.98 \pm 0.10$ & $0.14 \pm 0.05$ \\
\hline & 0.5 & $5.44 \pm 0.50$ & $0.19 \pm 0.09$ \\
\hline \multirow[t]{5}{*}{$\mathrm{CaSO}_{3}$} & 0.25 & $4.21 \pm 0.07$ & $0.79 \pm 0.27$ \\
\hline & 0.5 & $4.24 \pm 0.11$ & $1.22 \pm 0.45$ \\
\hline & 1.0 & $4.30 \pm 0.15$ & $2.19 \pm 0.84$ \\
\hline & 2.0 & $4.40 \pm 0.10$ & $4.56 \pm 1.22$ \\
\hline & 3.0 & $4.48 \pm 0.05$ & $6.92 \pm 1.42$ \\
\hline \multirow[t]{5}{*}{$\mathrm{CaSO}_{4}$} & 5 & $4.16 \pm 0.04$ & $1.05 \pm 0.29$ \\
\hline & 10 & $4.19 \pm 0.05$ & $1.05 \pm 0.15$ \\
\hline & 25 & $4.24 \pm 0.07$ & $1.12 \pm 0.08$ \\
\hline & 50 & $4.28 \pm 0.07$ & $1.16 \pm 0.07$ \\
\hline & 75 & $4.40 \pm 0.06$ & $1.06 \pm 0.07$ \\
\hline \multirow[t]{5}{*}{ FGD-22 } & 5 & $4.44 \pm 0.12$ & $1.06 \pm 0.09$ \\
\hline & 10 & $4.86 \pm 0.17$ & $1.10 \pm 0.05$ \\
\hline & 25 & $6.28 \pm 0.14$ & $1.17 \pm 0.08$ \\
\hline & 50 & $6.89 \pm 0.14$ & $1.24 \pm 0.05$ \\
\hline & 75 & $7.02 \pm 0.13$ & $1.24 \pm 0.08$ \\
\hline \multirow[t]{5}{*}{ FGD-27 } & 1.0 & $4.33 \pm 0.11$ & $1.02 \pm 0.14$ \\
\hline & 2.5 & $4.82 \pm 0.16$ & $1.46 \pm 0.16$ \\
\hline & 5.0 & $5.65 \pm 0.16$ & $1.93 \pm 0.14$ \\
\hline & 10 & $6.73 \pm 0.13$ & $2.25 \pm 0.11$ \\
\hline & 25 & $7.85 \pm 0.14$ & $2.50 \pm 0.16$ \\
\hline \multirow[t]{5}{*}{ FGD-28 } & 0.25 & $4.09 \pm 0.10$ & $0.28 \pm 0.09$ \\
\hline & 0.5 & $4.14 \pm 0.10$ & $0.46 \pm 0.10$ \\
\hline & 1.0 & $4.20 \pm 0.10$ & $0.76 \pm 0.13$ \\
\hline & 2.0 & $4.49 \pm 0.14$ & $1.19 \pm 0.16$ \\
\hline & 3.0 & $5.01 \pm 0.15$ & $1.46 \pm 0.11$ \\
\hline
\end{tabular}

\section{Plant Growth}

\section{Legumes}

The alfalfa cultivar grew very poorly in unamended acidic soil compared to the white clover cultivar (Tables 3 and 4). Both legumes grew quite well 
Table 3. Alfalfa shoot, root, and total dry matter (DM), shoot/root (S/R) DM ratio, and total and specific root lengths when grown in acidic soil amended with various levels of $\mathrm{CaCO}_{3}, \mathrm{CaSO}_{3}, \mathrm{CaSO}_{4}$, and three FGDs.

\begin{tabular}{|c|c|c|c|c|c|c|c|}
\hline \multirow[b]{3}{*}{ Treatment } & \multirow{3}{*}{$\begin{array}{c}\text { Level } \\
\text { (\% in } \\
\text { soil) }\end{array}$} & \multicolumn{4}{|c|}{$\begin{array}{l}\text { Plant dry matter } \\
\left(\mathrm{mg} \mathrm{plant}^{-1}\right)\end{array}$} & \multirow{2}{*}{\multicolumn{2}{|c|}{ Root length }} \\
\hline & & & & & & & \\
\hline & & Shoots & Roots & Total & $\begin{array}{l}\mathrm{DM} \\
\text { ratio }\end{array}$ & $\begin{array}{c}\text { Total } \\
\left(\mathrm{m} \mathrm{plant}^{-1}\right)\end{array}$ & $\begin{array}{c}\text { Specific } \\
\left(\mathrm{m} \mathrm{g}^{-1} \mathrm{DM}\right)\end{array}$ \\
\hline Control & 0 & 3.7 & 4.6 & 8.3 & 0.80 & 0.5 & 118 \\
\hline \multirow[t]{3}{*}{$\mathrm{CaCO}_{3}$} & 0.133 & 198 & 418 & 616 & 0.48 & 41.0 & 100 \\
\hline & 0.25 & 325 & 668 & 993 & 0.48 & 40.4 & 60 \\
\hline & 0.5 & 347 & 649 & 996 & 0.55 & 26.0 & 52 \\
\hline \multirow[t]{5}{*}{$\mathrm{CaSO}_{3}$} & 0.25 & 9.2 & 14.3 & 23.5 & 0.65 & 1.7 & 119 \\
\hline & 0.5 & 7.3 & 9.2 & 16.5 & 0.78 & 1.1 & 118 \\
\hline & 1.0 & 4.7 & 4.5 & 9.2 & 1.36 & 0.4 & 73 \\
\hline & 2.0 & $\mathrm{D}$ & $\mathrm{D}$ & $\mathrm{D}$ & $\mathrm{D}$ & $\mathrm{D}$ & $\mathrm{D}$ \\
\hline & 3.0 & $\mathrm{D}$ & $\mathrm{D}$ & $\mathrm{D}$ & $\mathrm{D}$ & $\mathrm{D}$ & $\mathrm{D}$ \\
\hline \multirow[t]{5}{*}{$\mathrm{CaSO}_{4}$} & 5 & 5.3 & 10.4 & 15.6 & 0.56 & 1.1 & 114 \\
\hline & 10 & 19.4 & 31.5 & 50.9 & 0.61 & 4.0 & 116 \\
\hline & 25 & 29.6 & 34.8 & 64.3 & 0.89 & 3.2 & 92 \\
\hline & 50 & 100.3 & 106.1 & 206.3 & 0.98 & 16.5 & 151 \\
\hline & 75 & 156.8 & 303.6 & 460.4 & 0.52 & 29.8 & 98 \\
\hline \multirow[t]{5}{*}{ FGD-22 } & 5 & 270 & 427 & 697 & 0.65 & 39.5 & 94 \\
\hline & 10 & 351 & 783 & 1134 & 0.45 & 51.0 & 63 \\
\hline & 25 & 581 & 1034 & 1615 & 0.56 & 52.6 & 50 \\
\hline & 50 & 578 & 784 & 1361 & 0.73 & 40.0 & 54 \\
\hline & 75 & 520 & 598 & 1119 & 0.90 & 36.7 & 59 \\
\hline \multirow[t]{5}{*}{ FGD-27 } & 1.0 & 248 & 437 & 684 & 0.63 & 50.4 & 114 \\
\hline & 2.5 & 354 & 766 & 1120 & 0.47 & 46.9 & 61 \\
\hline & 5.0 & 393 & 822 & 1215 & 0.49 & 42.9 & 53 \\
\hline & 10 & 378 & 707 & 1035 & 0.54 & 30.2 & 42 \\
\hline & 25 & 76 & 79 & 155 & 1.00 & 6.8 & 83 \\
\hline \multirow[t]{5}{*}{ FGD-28 } & 0.25 & 12.0 & 12.7 & 24.7 & 1.04 & 1.9 & 145 \\
\hline & 0.5 & 23.2 & 26.7 & 49.9 & 0.80 & 3.7 & 132 \\
\hline & 1.0 & 44.8 & 54.6 & 99.4 & 0.96 & 8.2 & 145 \\
\hline & 2.0 & 137.4 & 153.4 & 290.8 & 0.93 & 17.9 & 120 \\
\hline & 3.0 & 132.2 & 111.1 & 243.3 & 1.36 & 11.4 & 111 \\
\hline $\begin{array}{l}\text { LSD } \\
\qquad(\mathrm{P}<0.05)\end{array}$ & & 14.1 & 20.6 & 32.3 & 0.06 & 1.8 & 5 \\
\hline
\end{tabular}




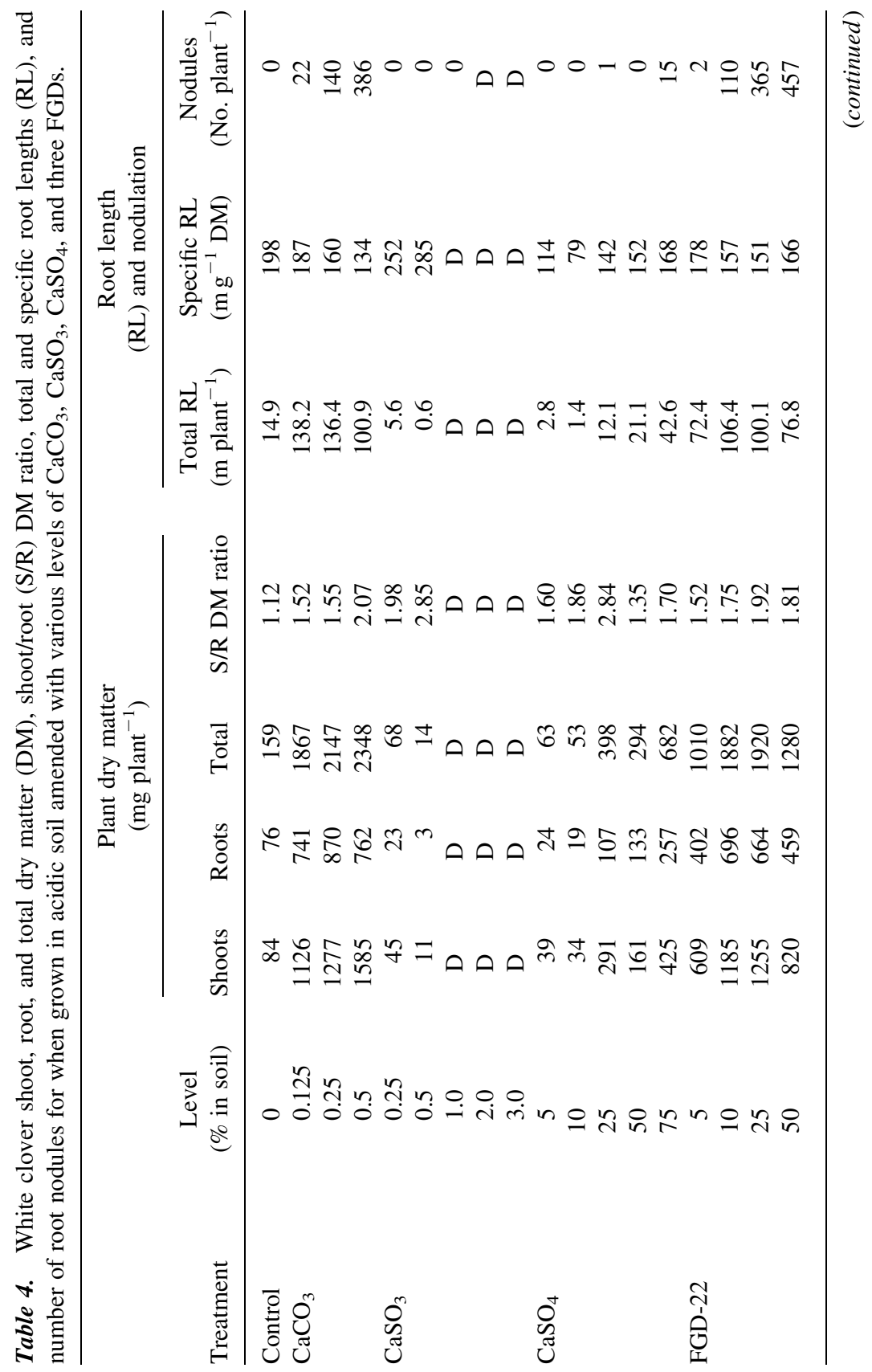




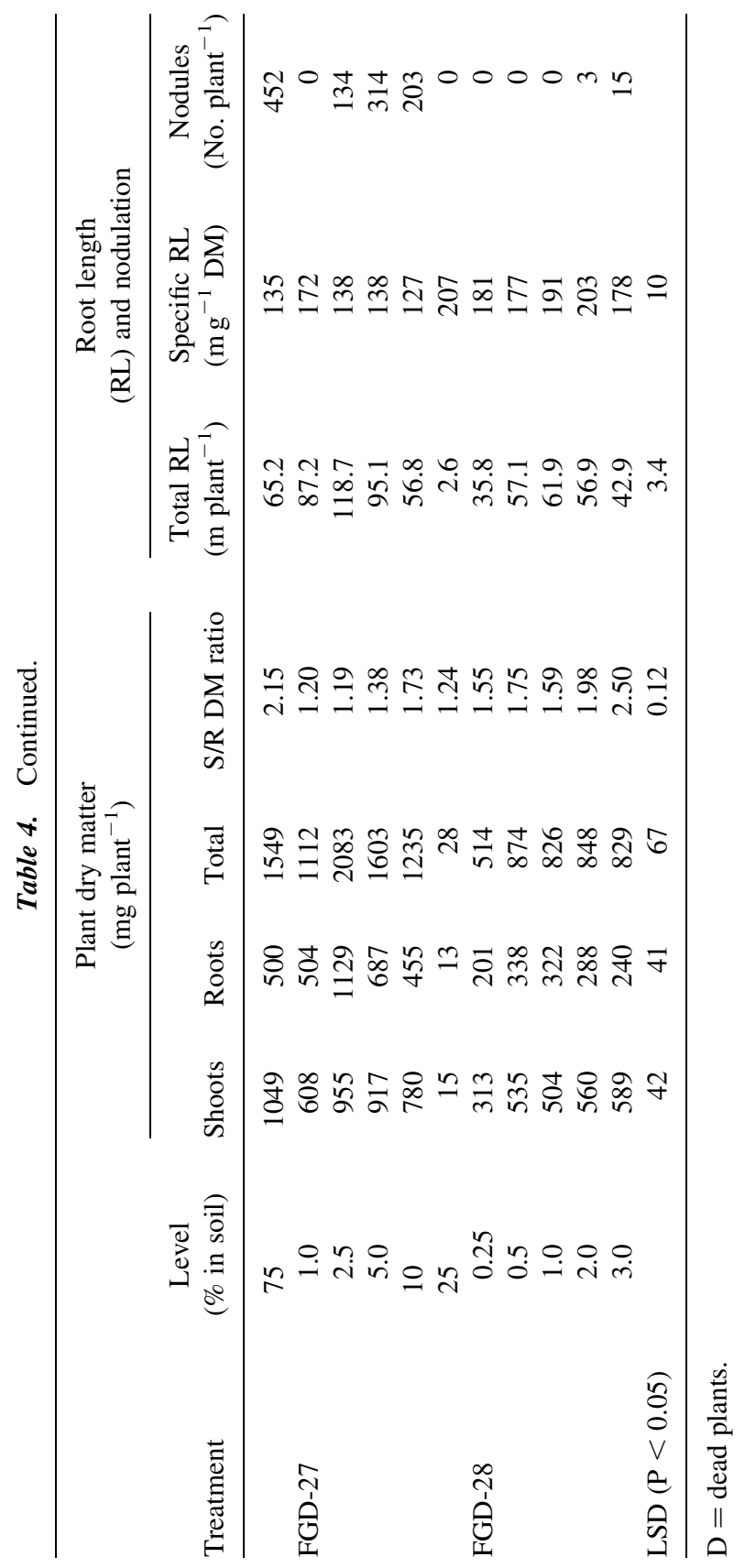


in soil receiving the various amendments. With only few exceptions, alfalfa root DM was greater than shoot DM when plants were grown with the various levels of control compounds and FGDs (Table 3), while shoot DM was greater than root DM for white clover (Table 4). Thus, shoot/root DM ratios for alfalfa were lower (mostly $<1.0$ ) compared to white clover $(>1.0)$ (Tables 3 and 4 ). The most effective amendments for enhancing legume growth at the lowest levels added to soil were $\mathrm{CaCO}_{3}, \mathrm{FGD}-22$, and FGD-27. Increases in total DM at the lowest levels of added amendment over unamended soil were between 74- and 84-fold for alfalfa and only 10- to 13-fold for white clover. The DM of each legume continued to increase as level of $\mathrm{CaCO}_{3}, \mathrm{FGD}-22$, and FGD-27 increased in soil, and were maximum at 25\% FGD-22 and 5.0\% FGD-27 for alfalfa and 2.5\% FGD-27 for white clover before DM decreased. Of the amendments tested, plants grown with $\mathrm{CaCO}_{3}$, FGD-22, and FGD-27 had highest DM. Both alfalfa and white clover grown in soil amended with $\mathrm{CaSO}_{3}$ grew poorly and plants died as $\mathrm{CaSO}_{3}$ levels increased. Alfalfa and white clover grown in soil amended with $\mathrm{CaSO}_{4}$ and FGD-28 had relatively low total DM at the lowest levels added. As level of these amendments increased, DM of alfalfa increased consistently, while white clover remained relatively constant. Maximum DM for plants grown with $\mathrm{CaSO}_{4}$ and FGD-28 were consistently lower than for plants grown with $\mathrm{CaCO}_{3}$, FGD-22, and FGD-27.

Total RL of both legumes followed trends similar to root DM, and both species had relatively high RL values (Tables 3 and 4). Overall SRL values for alfalfa were lowest in soil amended with FGD-22, FGD-27, and the highest level of $\mathrm{CaCO}_{3}$ compared to the other amendments (Table 3), while SRL values for white clover remained relatively constant over the various levels of amendment added (Table 4). Specific RL values for alfalfa grown with $\mathrm{CaSO}_{4}$ and FGD-28 were relatively similar to or only slightly higher than for plants grown in unamended soil. $\mathrm{CaCO}_{3}$, FGD-22, and FGD-27 were effective in enhancing nodule formation on roots of white clover, while $\mathrm{CaSO}_{3}, \mathrm{CaSO}_{4}$, and FGD-28 were ineffective (Table 4).

\section{Cool-Season Grasses}

The orchardgrass cultivar grew considerably better in unamended soil than the tall fescue cultivar, but differences between plant DM increases with low levels of added amendment were considerably greater for tall fescue than for orchardgrass (Tables 5 and 6). Root DM was consistently higher for both of these cool-season grasses than shoot DM, and shoot/root DM ratios were generally lower for tall fescue than for orchardgrass (Tables 5 and 6). Both of these plant species had good growth when soil was amended with $\mathrm{CaCO}_{3}$, 
Table 5. Orchardgrass shoot, root, and total dry matter (DM), shoot/root (S/R) DM ratio, and total and specific root lengths when grown in acidic soil amended with various levels of $\mathrm{CaCO}_{3}, \mathrm{CaSO}_{3}, \mathrm{CaSO}_{4}$, and three FGDs.

\begin{tabular}{|c|c|c|c|c|c|c|c|}
\hline \multirow[b]{3}{*}{ Treatment } & \multirow{3}{*}{$\begin{array}{c}\text { Level } \\
\text { (\% in } \\
\text { soil) }\end{array}$} & \multicolumn{4}{|c|}{$\begin{array}{l}\text { Plant dry matter } \\
\left(\mathrm{mg} \mathrm{plant}^{-1}\right)\end{array}$} & \multirow{2}{*}{\multicolumn{2}{|c|}{ Root length }} \\
\hline & & & & & & & \\
\hline & & Shoots & Roots & Total & $\begin{array}{l}\mathrm{DM} \\
\text { ratio }\end{array}$ & $\begin{array}{c}\text { Total } \\
\left(\mathrm{m} \mathrm{plant}^{-1}\right)\end{array}$ & $\begin{array}{c}\text { Specific } \\
\left(\mathrm{m} \mathrm{g}^{-1} \mathrm{DM}\right)\end{array}$ \\
\hline Control & 0 & 273 & 58 & 331 & 7.09 & 25 & 866 \\
\hline \multirow{3}{*}{$\mathrm{CaCO}_{3}$} & 0.125 & 757 & 653 & 1409 & 1.19 & 146 & 232 \\
\hline & 0.25 & 1048 & 1648 & 2696 & 0.65 & 371 & 226 \\
\hline & 0.5 & 810 & 2586 & 3396 & 0.44 & 362 & 141 \\
\hline \multirow[t]{5}{*}{$\mathrm{CaSO}_{3}$} & 0.25 & 68 & 19 & 87 & 5.55 & 4 & 248 \\
\hline & 0.5 & 99 & 30 & 375 & 8.15 & 4 & 200 \\
\hline & 1.0 & 143 & 125 & 268 & 6.12 & 16 & 223 \\
\hline & 2.0 & 133 & 167 & 300 & 10.35 & $<1$ & 123 \\
\hline & 3.0 & 261 & 109 & 370 & 6.03 & 28 & 276 \\
\hline \multirow[t]{5}{*}{$\mathrm{CaSO}_{4}$} & 5 & 272 & 59 & 331 & 4.83 & 19 & 313 \\
\hline & 10 & 548 & 875 & 1423 & 1.98 & 115 & 191 \\
\hline & 25 & 839 & 849 & 1688 & 1.05 & 166 & 209 \\
\hline & 50 & 971 & 1648 & 2618 & 0.64 & 258 & 170 \\
\hline & 75 & 1177 & 2014 & 3191 & 0.67 & 231 & 123 \\
\hline \multirow[t]{5}{*}{ FGD-22 } & 5 & 1104 & 2775 & 3879 & 0.45 & 335 & 140 \\
\hline & 10 & 1139 & 1879 & 3018 & 0.64 & 296 & 159 \\
\hline & 25 & 974 & 3310 & 4283 & 0.40 & 395 & 148 \\
\hline & 50 & 511 & 1592 & 2103 & 0.34 & 242 & 158 \\
\hline & 75 & 336 & 856 & 1192 & 0.43 & 178 & 221 \\
\hline \multirow[t]{5}{*}{ FGD-27 } & 1.0 & 1236 & 3279 & 4515 & 0.45 & 303 & 102 \\
\hline & 2.5 & 1321 & 3481 & 4801 & 0.41 & 372 & 112 \\
\hline & 5.0 & 1566 & 2501 & 1067 & 0.71 & 361 & 158 \\
\hline & 10 & 1482 & 1657 & 3139 & 0.93 & 255 & 156 \\
\hline & 25 & 965 & 796 & 1761 & 1.23 & 113 & 146 \\
\hline \multirow[t]{5}{*}{ FGD-28 } & 0.25 & 1153 & 3570 & 4723 & 0.33 & 328 & 93 \\
\hline & 0.5 & 1092 & 2334 & 3426 & 0.55 & 311 & 145 \\
\hline & 1.0 & 1246 & 2694 & 3939 & 0.52 & 312 & 126 \\
\hline & 2.0 & 1236 & 2534 & 3770 & 0.51 & 326 & 132 \\
\hline & 3.0 & 1203 & 2193 & 3395 & 0.56 & 286 & 136 \\
\hline $\begin{array}{l}\text { LSD } \\
\qquad(\mathrm{P}<0.05)\end{array}$ & & 28 & 167 & 174 & 0.61 & 31 & 43 \\
\hline
\end{tabular}


Table 6. Tall fescue shoot, root, and total dry matter (DM), shoot/root (S/R) DM ratio, and total and specific root lengths when grown in acidic soil amended with various levels of $\mathrm{CaCO}_{3}, \mathrm{CaSO}_{3}, \mathrm{CaSO}_{4}$, and three FGDs.

\begin{tabular}{|c|c|c|c|c|c|c|c|}
\hline \multirow[b]{3}{*}{ Treatment } & \multirow{3}{*}{$\begin{array}{c}\text { Level } \\
\text { (\% in } \\
\text { soil) }\end{array}$} & \multicolumn{4}{|c|}{$\begin{array}{l}\text { Plant dry matter } \\
\left(\mathrm{mg} \mathrm{plant}^{-1}\right)\end{array}$} & \multirow{2}{*}{\multicolumn{2}{|c|}{ Root length }} \\
\hline & & & & & & & \\
\hline & & Shoots & Roots & Total & $\begin{array}{l}\mathrm{DM} \\
\text { ratio }\end{array}$ & $\begin{array}{c}\text { Total } \\
\left(\mathrm{m} \mathrm{plant}^{-1}\right)\end{array}$ & $\begin{array}{c}\text { Specific } \\
\left(\mathrm{m} \mathrm{g}^{-1} \mathrm{DM}\right)\end{array}$ \\
\hline Control & 0 & 29 & 5 & 33 & 0.63 & 2 & 311 \\
\hline \multirow{3}{*}{$\mathrm{CaCO}_{3}$} & 0.125 & 1373 & 4523 & 5896 & 0.31 & 522 & 113 \\
\hline & 0.25 & 1576 & 6909 & 8486 & 0.27 & 393 & 60 \\
\hline & 0.5 & 1627 & 5247 & 6874 & 0.33 & 497 & 100 \\
\hline \multirow[t]{5}{*}{$\mathrm{CaSO}_{3}$} & 0.25 & 10 & 3 & 13 & 3.20 & $<1$ & 147 \\
\hline & 0.5 & 5 & 1 & 6 & 4.87 & $<1$ & 123 \\
\hline & 1.0 & 5 & 2 & 7 & 2.68 & $<1$ & 64 \\
\hline & 2.0 & 4 & 1 & 6 & 3.55 & $<1$ & 60 \\
\hline & 3.0 & 40 & 6 & 46 & 6.99 & 2 & 257 \\
\hline \multirow[t]{5}{*}{$\mathrm{CaSO}_{4}$} & 5 & 11 & 2 & 14 & 5.05 & $<1$ & 240 \\
\hline & 10 & 43 & 9 & 52 & 4.78 & 2 & 298 \\
\hline & 25 & 278 & 82 & 360 & 5.30 & 15 & 250 \\
\hline & 50 & 1106 & 3083 & 4190 & 0.48 & 320 & 109 \\
\hline & 75 & 1228 & 9788 & 11770 & 0.12 & 567 & 54 \\
\hline \multirow[t]{5}{*}{ FGD-22 } & 5 & 1140 & 5156 & 6295 & 0.25 & 398 & 81 \\
\hline & 10 & 1230 & 8942 & 10170 & 0.14 & 572 & 64 \\
\hline & 25 & 1082 & 7225 & 8307 & 0.22 & 527 & 111 \\
\hline & 50 & 635 & 2364 & 2999 & 0.30 & 360 & 163 \\
\hline & 75 & 352 & 1348 & 1700 & 0.28 & 273 & 202 \\
\hline \multirow[t]{5}{*}{ FGD-27 } & 1.0 & 1488 & 2567 & 4055 & 0.65 & 301 & 136 \\
\hline & 2.5 & 1319 & 2334 & 3653 & 0.57 & 355 & 151 \\
\hline & 5.0 & 1352 & 2295 & 3647 & 0.60 & 409 & 177 \\
\hline & 10 & 1658 & 2477 & 4135 & 0.73 & 264 & 114 \\
\hline & 25 & 1086 & 1032 & 2118 & 1.20 & 148 & 140 \\
\hline \multirow[t]{5}{*}{ FGD-28 } & 0.25 & 1184 & 1203 & 2387 & 1.00 & 226 & 192 \\
\hline & 0.5 & 1335 & 2234 & 3569 & 0.62 & 322 & 150 \\
\hline & 1.0 & 1301 & 2700 & 4001 & 0.51 & 383 & 147 \\
\hline & 2.0 & 1626 & 3218 & 4844 & 0.60 & 420 & 149 \\
\hline & 3.0 & 1451 & 2943 & 4394 & 0.57 & 355 & 128 \\
\hline $\begin{array}{l}\text { LSD } \\
\qquad(\mathrm{P}<0.05\end{array}$ & & 27 & 267 & 286 & 0.48 & 14 & 12 \\
\hline
\end{tabular}


$\mathrm{CaSO}_{4}$, and the FGDs. Highest orchardgrass DM was obtained when plants were grown with $0.5 \% \mathrm{CaCO}_{3}, 75 \% \mathrm{CaSO}_{4}, 25 \%$ FGD-22, $2.5 \%$ FGD-27, and $0.25 \%$ FGD-28 (Table 5), and highest tall fescue DM was obtained when plants were grown with $0.25 \% \mathrm{CaCO}_{3}, 75 \% \mathrm{CaSO}_{4}, 10 \%$ FGD-22, $10 \%$ FGD27, and 2.0\% FGD-28 (Table 6). Orchardgrass grew fairly well with additions of $\mathrm{CaSO}_{3}$, but tall fescue did not. Both of these cool-season grasses had consistent increases in $\mathrm{DM}$ as level of $\mathrm{CaSO}_{4}$ increased, but the response of tall fescue was more dramatic than orchardgrass $(>350$-fold for tall fescue compared to 10 -fold for orchardgrass between 5 and $75 \%$ of added $\mathrm{CaSO}_{4}$ ). The DM of orchardgrass and tall fescue grown with the lowest level of $\mathrm{CaSO}_{4}$ $(5 \%)$ was no higher and even below that of plants grown in unamended soil before increasing extensively as level of $\mathrm{CaSO}_{4}$ increased. In the case of tall fescue, increases in DM did not resume until $\mathrm{CaSO}_{4}$ level was above $10 \%$. Except for plants grown with $\mathrm{CaSO}_{3}$, both orchardgrass and tall fescue had extensive RL in amended soil (Tables 5 and 6). Both species grown with the amendments had lower SRL values than plants grown in unamended soil (Tables 5 and 6). Orchardgrass generally had lower SRL values when grown with FGDs than with $\mathrm{CaCO}_{3}, \mathrm{CaSO}_{4}$, and $\mathrm{CaSO}_{3}$, while tall fescue had lower SRL values when grown with $\mathrm{CaCO}_{3}, \mathrm{CaSO}_{3}$, and each of the FGDs compared to $\mathrm{CaSO}_{4}$.

\section{Warm-Season Grasses}

Both warm-season grasses grew well in unamended soil, and DM yields with added amendments were only 2- to 3-fold magnitude higher than those of plants grown in unamended soil (Tables 7 and 8). Shoot DM was higher than root DM for each of these species, and shoot/root DM ratios of eastern gamagrass were generally higher than those for switchgrass (Tables 7 and 8). Added $\mathrm{CaCO}_{3}$ improved growth of these plant species by only $\sim 2$-fold, with switchgrass having slightly more positive responses than eastern gamagrass. The lower levels of $\mathrm{CaSO}_{3}$ had no or relatively minor negative effects on DM of both switchgrass and eastern gamagrass, but plants grew very little or were dead at the highest levels of $\mathrm{CaSO}_{3}$. Both species had DM increases from added FGDs at the lower levels, but decreased at the higher levels. Eastern gamagrass grown with 5 and $10 \% \mathrm{CaSO}_{4}$ levels had lower DM than plants grown in unamended soil before increasing at the highest $\mathrm{CaSO}_{4}$ levels (Table 8 ), and switchgrass had DM increases when plants were grown with all levels of $\mathrm{CaSO}_{4}$ (Table 7). Total RL was relatively good for these warm-season grasses grown with the various amendments added, except $\mathrm{CaSO}_{3}$ (Tables 7 and 8). Specific RL values of switchgrass were generally lower for plants 
Table 7. Switchgrass shoot, root, and total dry matter (DM), shoot/root (S/R) DM ratio, and total and specific root lengths when grown in acidic soil amended with various levels of $\mathrm{CaCO}_{3}, \mathrm{CaSO}_{3}, \mathrm{CaSO}_{4}$, and three FGDs.

\begin{tabular}{|c|c|c|c|c|c|c|c|}
\hline \multirow[b]{3}{*}{ Treatment } & \multirow{3}{*}{$\begin{array}{c}\text { Level } \\
\text { (\% in } \\
\text { soil) }\end{array}$} & \multicolumn{4}{|c|}{$\begin{array}{l}\text { Plant dry matter } \\
\left(\mathrm{mg} \mathrm{plant}^{-1}\right)\end{array}$} & \multirow{2}{*}{\multicolumn{2}{|c|}{ Root length }} \\
\hline & & & & & & & \\
\hline & & Shoots & Roots & Total & $\begin{array}{l}\mathrm{DM} \\
\text { ratio }\end{array}$ & $\begin{array}{c}\text { Total } \\
\left(\mathrm{m} \mathrm{plant}^{-1}\right)\end{array}$ & $\begin{array}{c}\text { Specific } \\
\left(\mathrm{mg}^{-1} \mathrm{DM}\right)\end{array}$ \\
\hline Control & 0 & 659 & 220 & 879 & 5.44 & 25.1 & 143 \\
\hline \multirow[t]{3}{*}{$\mathrm{CaCO}_{3}$} & 0.125 & 921 & 719 & 1640 & 1.30 & 77.2 & 105 \\
\hline & 0.25 & 1160 & 894 & 2054 & 1.33 & 80.1 & 88 \\
\hline & 0.5 & 1023 & 896 & 1919 & 1.18 & 60.3 & 65 \\
\hline \multirow[t]{5}{*}{$\mathrm{CaSO}_{3}$} & 0.25 & 713 & 338 & 1051 & 2.34 & 37.4 & 90 \\
\hline & 0.5 & 213 & 116 & 329 & 3.90 & 6.1 & 108 \\
\hline & 1.0 & 148 & 68 & 215 & 2.18 & 4.6 & 92 \\
\hline & 2.0 & 64 & 2 & 66 & 32.25 & 0.4 & 100 \\
\hline & 3.0 & 11 & 2 & 13 & 5.50 & 0.2 & 180 \\
\hline \multirow[t]{5}{*}{$\mathrm{CaSO}_{4}$} & 5 & 1202 & 674 & 1875 & 1.88 & 64.9 & 97 \\
\hline & 10 & 1111 & 723 & 1834 & 1.64 & 71.9 & 98 \\
\hline & 25 & 1576 & 838 & 2413 & 2.02 & 72.7 & 85 \\
\hline & 50 & 995 & 461 & 1456 & 2.26 & 37.9 & 88 \\
\hline & 75 & 944 & 433 & 1377 & 2.41 & 36.8 & 88 \\
\hline \multirow[t]{5}{*}{ FGD-22 } & 5 & 1346 & 1238 & 2584 & 1.14 & 81.0 & 65 \\
\hline & 10 & 1568 & 1304 & 2872 & 1.26 & 104.7 & 78 \\
\hline & 25 & 1486 & 1187 & 2673 & 1.30 & 93.8 & 78 \\
\hline & 50 & 701 & 400 & 1100 & 1.80 & 50.3 & 122 \\
\hline & 75 & 431 & 290 & 721 & 1.58 & 30.8 & 117 \\
\hline \multirow[t]{5}{*}{ FGD-27 } & 1.0 & 1071 & 983 & 2054 & 1.09 & 92.7 & 93 \\
\hline & 2.5 & 1352 & 873 & 2224 & 1.58 & 85.1 & 98 \\
\hline & 5.0 & 1303 & 722 & 2025 & 1.81 & 65.7 & 90 \\
\hline & 10 & 910 & 450 & 1360 & 2.07 & 36.8 & 83 \\
\hline & 25 & 14 & 14 & 28 & 1.03 & 1.1 & 82 \\
\hline \multirow[t]{5}{*}{ FGD-28 } & 0.25 & 959 & 657 & 1616 & 1.55 & 73.0 & 115 \\
\hline & 0.5 & 1054 & 778 & 1832 & 1.46 & 74.5 & 97 \\
\hline & 1.0 & 1314 & 868 & 2182 & 1.59 & 92.0 & 105 \\
\hline & 2.0 & 1111 & 737 & 1848 & 1.52 & 65.1 & 90 \\
\hline & 3.0 & 912 & 420 & 1332 & 2.23 & 37.1 & 90 \\
\hline \multicolumn{2}{|c|}{$\begin{array}{l}\text { LSD } \\
\qquad(\mathrm{P}<0.05)\end{array}$} & 32 & 30 & 54 & 0.56 & 28.3 & 11 \\
\hline
\end{tabular}


Table 8. Eastern gamagrass shoot, root, and total dry matter (DM), shoot/root (S/R) $\mathrm{DM}$ ratio, and total and specific root lengths when grown in acidic soil amended with various levels of $\mathrm{CaCO}_{3}, \mathrm{CaSO}_{3}, \mathrm{CaSO}_{4}$, and three FGDs.

\begin{tabular}{|c|c|c|c|c|c|c|c|}
\hline \multirow[b]{3}{*}{ Treatment } & \multirow{3}{*}{$\begin{array}{l}\text { Level } \\
\text { (\% in } \\
\text { soil) }\end{array}$} & \multicolumn{4}{|c|}{$\begin{array}{l}\text { Plant dry matter } \\
\left(\mathrm{mg} \mathrm{plant}^{-1}\right)\end{array}$} & \multirow{2}{*}{\multicolumn{2}{|c|}{ Root length }} \\
\hline & & & & & & & \\
\hline & & Shoots & Roots & Total & $\begin{array}{l}\mathrm{DM} \\
\text { ratio }\end{array}$ & $\begin{array}{c}\text { Total } \\
\left(\mathrm{m}^{\text {plant }}{ }^{-1}\right)\end{array}$ & $\begin{array}{c}\text { Specific } \\
\left(\mathrm{mg}^{-1} \mathrm{DM}\right)\end{array}$ \\
\hline Control & 0 & 577 & 247 & 824 & 2.36 & 18.0 & 74 \\
\hline \multirow{3}{*}{$\mathrm{CaCO}_{3}$} & 0.125 & 946 & 564 & 1510 & 1.70 & 43.4 & 78 \\
\hline & 0.25 & 845 & 611 & 1456 & 1.44 & 41.5 & 68 \\
\hline & 0.5 & 586 & 387 & 972 & 1.52 & 29.4 & 75 \\
\hline \multirow[t]{5}{*}{$\mathrm{CaSO}_{3}$} & 0.25 & 600 & 229 & 828 & 2.78 & 16.1 & 70 \\
\hline & 0.5 & 679 & 228 & 907 & 5.89 & 19.3 & 152 \\
\hline & 1.0 & 252 & 55 & 306 & 4.58 & 3.3 & 49 \\
\hline & 2.0 & $\mathrm{D}$ & $\mathrm{D}$ & $\mathrm{D}$ & $\mathrm{D}$ & $\mathrm{D}$ & $\mathrm{D}$ \\
\hline & 3.0 & $\mathrm{D}$ & $\mathrm{D}$ & $\mathrm{D}$ & $\mathrm{D}$ & $\mathrm{D}$ & $\mathrm{D}$ \\
\hline \multirow[t]{5}{*}{$\mathrm{CaSO}_{4}$} & 5 & 369 & 129 & 498 & 3.10 & 7.7 & 59 \\
\hline & 10 & 411 & 153 & 564 & 2.58 & 8.7 & 58 \\
\hline & 25 & 642 & 214 & 856 & 2.94 & 12.8 & 63 \\
\hline & 50 & 1176 & 377 & 1553 & 3.24 & 24.9 & 68 \\
\hline & 75 & 1331 & 408 & 1738 & 3.34 & 31.3 & 76 \\
\hline \multirow[t]{5}{*}{ FGD-22 } & 5 & 1099 & 646 & 1746 & 1.70 & 54.7 & 85 \\
\hline & 10 & 1374 & 492 & 1866 & 2.79 & 60.3 & 74 \\
\hline & 25 & 351 & 458 & 810 & 2.56 & 6.7 & 67 \\
\hline & 50 & 215 & 85 & 300 & 1.69 & 5.7 & 34 \\
\hline & 75 & 293 & 99 & 392 & 3.45 & 5.7 & 55 \\
\hline \multirow[t]{5}{*}{ FGD-27 } & 1.0 & 972 & 498 & 1470 & 1.97 & 40.2 & 83 \\
\hline & 2.5 & 802 & 456 & 1258 & 1.90 & 36.3 & 77 \\
\hline & 5.0 & 700 & 388 & 1087 & 1.84 & 25.7 & 66 \\
\hline & 10 & 364 & 148 & 512 & 2.54 & 9.3 & 62 \\
\hline & 25 & 91 & 26 & 117 & 3.43 & 1.0 & 40 \\
\hline \multirow[t]{5}{*}{ FGD-28 } & 0.25 & 667 & 388 & 1045 & 1.77 & 33.1 & 88 \\
\hline & 0.5 & 996 & 594 & 1590 & 1.68 & 52.9 & 89 \\
\hline & 1.0 & 1294 & 706 & 2001 & 1.83 & 58.8 & 82 \\
\hline & 2.0 & 1225 & 692 & 1917 & 1.77 & 58.6 & 84 \\
\hline & 3.0 & 602 & 295 & 896 & 2.12 & 27.9 & 95 \\
\hline $\begin{array}{l}\text { LSD } \\
\qquad(\mathrm{P}<0.05)\end{array}$ & & 55 & 38 & 83 & 1.32 & 2.6 & 7 \\
\hline
\end{tabular}

$\mathrm{D}=$ dead plants. 
grown in amended compared to unamended soil (Table 7), while amendments had relatively little effect on SRL values of eastern gamagrass, except at the highest levels of FGD-22 and FGD-27 where they were lower (Table 8).

\section{DISCUSSION}

Increased soil $\mathrm{pH}_{\mathrm{Ca}}$ was expected from $\mathrm{CaCO}_{3}$ (lime), and only limited increases in soil $\mathrm{pH}_{\mathrm{Ca}}$ were expected from added $\mathrm{CaSO}_{3}$ and $\mathrm{CaSO}_{4}$ as both of these chemically pure compounds should have had no $\mathrm{CaCO}_{3}$ equivalency (CCE). Increases in soil $\mathrm{pH}_{\mathrm{Ca}}$ from the added FGDs indicated that these products contained some alkaline substance(s), which is consistent with CCE values measured in these products (Table 1). FGD-28 with its relatively high CCE (69\%) increased soil $\mathrm{pH}_{\mathrm{Ca}}$ consistently, even at low levels. FGD-27, even with its relatively low CCE (13\%), increased soil $\mathrm{pH}_{\mathrm{Ca}}$ to fairly high values at its highest level added to soil (25\%).

Chemical grade $\mathrm{CaCO}_{3}$ contained few soluble salts and/or did not increase availability of other salts once added to soil, thus this compound had little effect on soil EC. $\mathrm{CaSO}_{4}$ might be expected to increase soil EC to some extent, since this salt has some, although relatively low, solubility. ${ }^{[23]}$ However, $\mathrm{CaSO}_{4}$ would not be expected to increase soil EC beyond the level at which the soil solution would become saturated $(\sim 0.07 \%)$ due to its solubility limit. Changes in EC from added $\mathrm{CaSO}_{3}$ might be expected to be similar to that of $\mathrm{CaSO}_{4}$, since $\mathrm{CaSO}_{3}$ is readily oxidized to $\mathrm{CaSO}_{4}{ }^{[24]}$ Nevertheless, EC increases from added $\mathrm{CaSO}_{3}$ above that of $\mathrm{CaSO}_{4}$ occurred in soil where the various plant species, except orchardgrass, were grown. Relatively high soil EC from added $\mathrm{CaSO}_{3}$ may have been because of $\mathrm{HSO}_{3}^{-}$ formation in acidic soil, as this ion should be prominent in solution at low soil $\mathrm{pH}$ with added $\mathrm{CaSO}_{3} .{ }^{[25]}$ The increase in EC with added FGD-27 may have been due to formation of $\mathrm{MgSO}_{4} \cdot 7 \mathrm{H}_{2} \mathrm{O} .^{[21]}$

Only FGD-27 at its highest level increased soil $\mathrm{pH}_{\mathrm{Ca}}$ and $\mathrm{EC}$ sufficiently to potentially induce detrimental effects to plants. Soil at $\mathrm{pH} 7$ to 8 may induce deficiencies of $\mathrm{P}, \mathrm{Fe}, \mathrm{Zn}$, and/or Mn because solubilities of these minerals are reduced as soil $\mathrm{pH}$ increases. ${ }^{[26]}$ Except for added $\mathrm{CaSO}_{3}, \mathrm{EC}$ values resulting from added FGDs were generally not sufficiently high to detrimentally affect growth of most plants. Soil EC values reported to decrease growth of salt sensitive, moderately salt sensitive, and moderately salt tolerant plants have been $1.5,3.5$, and $6.5 \mathrm{dS} \mathrm{m}^{-1}$, respectively. ${ }^{[27]}$ Decreases in plant growth from added $\mathrm{CaSO}_{3}$ likely occurred because of $\mathrm{S}_{-} \mathrm{SO}_{3}$ toxicity rather than from high $\mathrm{EC}$, as $\mathrm{S}_{-} \mathrm{SO}_{3}$ even at low levels is known to be harmful to many plants. ${ }^{[28]}$ Increases in soil $\mathrm{pH}_{\mathrm{Ca}}$ and $\mathrm{EC}$ from the FGDs were likely because of alkalizing 
agents and soluble salts included in the products for stabilization. Both FGD27 and FGD-28 had relatively high $\mathrm{Mg}$ (Table 1), and $\mathrm{Mg}$ salts are usually more soluble than Ca salts. In addition, $\mathrm{Mg}$ in FGD-27 came from $\mathrm{Mg}(\mathrm{OH})_{2}(\mathrm{a}$ basic compound that can raise soil $\mathrm{pH}$ ), and the high $\mathrm{Ca}$ and $\mathrm{Mg}$ in FGD-28 (Table 1) may have come from additional $\mathrm{Ca}-\mathrm{Mg}$ incorporated into the product for stabilization $\left[\mathrm{Ca}-\mathrm{MgO}, \mathrm{Ca}-\mathrm{Mg}(\mathrm{OH})_{2}\right.$, and/or $\mathrm{Ca}-\mathrm{MgCO}_{3}$ ]. Even though it is not known what compounds were added to FGD-28, this

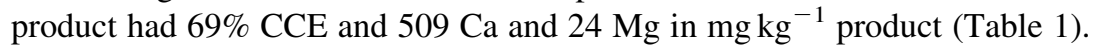
FGD-22 apparently had some added ingredients to increase soil $\mathrm{pH}$ and provide positive responses to plants at low levels. Plant growth responses from added FGD-22 were also quite different from those of chemical grade $\mathrm{CaSO}_{4}$.

The six forage species, as expected, had greater DM when grown with added $\mathrm{CaCO}_{3}$ compared to unamended soil, but the legumes and tall fescue responded more to added $\mathrm{CaCO}_{3}$ than orchardgrass and the warm-season grasses. Legumes are known to need relatively higher soil $\mathrm{pH}$ for optimal growth compared to grasses. ${ }^{[29,30]}$ Regardless of plant species, roots had greater positive effects from added $\mathrm{CaCO}_{3}$ than shoots. The unamended soil with $\mathrm{pH}_{\mathrm{Ca}} 3.9$ was detrimental to root growth, which was likely because of $\mathrm{Al}$ (and possibly $\mathrm{Mn}$ ) toxicity. Aluminum toxicity often restricts root length and diminishes acquisition of essential mineral nutrients. ${ }^{[31]}$ Since this batch of unamended soil had high $\mathrm{Al}$ (88\% saturation) and low $\mathrm{P}\left(3.1 \mathrm{mg} \mathrm{kg}^{-1}\right.$ soil), mineral nutrient toxicities and/or deficiencies would be expected. Phosphorus and $\mathrm{Mg}$ deficiencies were common on many plants grown in this and other low $\mathrm{pH}$ soils (R.B. Clark, personal observations). Reduced DM for grasses grown at the highest level of $\mathrm{CaCO}_{3}$ added may have occurred because of "overliming" stress effects sometimes associated with induced $\mathrm{P}, \mathrm{Mg}$, and/or other mineral deficiencies. ${ }^{[32,33]}$ Similar reductions in DM were noted for grasses in some of the early experiments in this series where $\mathrm{CaCO}_{3}$ was added up to $1 \%$ (R.B. Clark, unpublished data), and for maize grown in an acidic soil amended with $\mathrm{CaCO}_{3}$ at levels similar to those used in these experiments. ${ }^{[34]}$

Except for orchardgrass, switchgrass, and eastern gamagrass, plants grown with $\mathrm{CaSO}_{3}$ even at low levels did not grow well and were usually dead when grown with the highest levels. $\mathrm{S}_{-} \mathrm{SO}_{3}$ even at low levels is normally harmful to plants, ${ }^{[15,24,28,34]}$ and caution is needed if plants are to be grown in soil amended with FGDs containing $\mathrm{S}-\mathrm{SO}_{3}$. Since $\mathrm{S}-\mathrm{SO}_{3}$ is oxidized to $\mathrm{S}-\mathrm{SO}_{4}$ within relatively short time periods (days or weeks) ${ }^{[24,35]}$ and if sufficient exposure to oxygen/air and time are provided, soils receiving added $\mathrm{CaSO}_{3}$ should provide effects similar to those of $\mathrm{CaSO}_{4}$ once $\mathrm{S}_{-} \mathrm{SO}_{3}$ has been oxidized to $\mathrm{S}_{-} \mathrm{SO}_{4}$. Nevertheless, high soil $\mathrm{pH}$ and high soil moisture (lack of $\mathrm{O}_{2}$ ) can prolong time needed to convert $\mathrm{S}_{-} \mathrm{SO}_{3}$ to $\mathrm{S}-\mathrm{SO}_{4} \cdot{ }^{[35]}$ In addition, 
$\mathrm{CaSO}_{3}$ can release $\mathrm{SO}_{2}$ gas under acidic conditions, ${ }^{[25]}$ which is toxic to plants. ${ }^{[24]}$

$\mathrm{CaSO}_{4}$ had to be added at relatively high levels before enhancement effects on DM occurred, and DM of plants grown in soil with $5-10 \% \mathrm{CaSO}_{4}$ sometimes had lower DM than plants grown in unamended soil. These reductions in $\mathrm{DM}$ with low levels of $\mathrm{CaSO}_{4}$ might be attributed to induced $\mathrm{Al}$ toxicity to roots from $\mathrm{Ca}^{2+}$ displacement of $\mathrm{Al}^{3+}$ on soil exchange sites, ${ }^{[15]}$ although induced $\mathrm{Mg}$ deficiency from imbalanced $\mathrm{Ca}: \mathrm{Mg}$ ratios ${ }^{[36]}$ should not be ruled out. Once $\mathrm{CaSO}_{4}$ was added at higher levels to overcome detrimental effects in the soil, growth improved likely because of $\mathrm{Al}$ inactivation (e.g., formation of non-toxic $\mathrm{Ca}-\mathrm{Al}$ and/or $\mathrm{S}-\mathrm{Al}$ compounds) and because of increases in soil $\mathrm{pH}$ to values where $\mathrm{Al}$ would be inactivated $\left(\mathrm{pH}_{\mathrm{Ca}}\right.$ 5.5). ${ }^{[15,34]}$ Except for switchgrass, even the highest level of $\mathrm{CaSO}_{4}$ used in these experiments (75\% in soil mixes) was not detrimental to plant growth.

Added FGDs improved growth of the plants used in these studies. FGD27 and FGD-28 generally provided the best growth at the lowest levels added to soil. Many FGDs contain minerals added during generation and/or curing (stabilization) that provide enhancement effects to plants. Although many mineral disorders occur on plants grown in acidic soil, $\mathrm{Mg}$ deficiency and $\mathrm{Al}$ toxicity are commonly reported. ${ }^{[37]}$ The FGDs used in our studies appeared to contain added substances that enhanced growth, so that DM was equal to or greater than those obtained with chemical grade $\mathrm{CaCO}_{3}$ and $\mathrm{CaSO}_{4}$, which are major components of FGDs. Both FGD-27 and FGD-28 contained relatively high $\mathrm{Mg}$ and raised soil $\mathrm{pH}$ extensively, and these FGDs could have alleviated $\mathrm{Mg}$ deficiency and $\mathrm{Al}$ toxicity that might have otherwise been imposed on plants grown in this acidic soil. Even though FGD-22 functioned somewhat similar to pure $\mathrm{CaSO}_{4}$, this product appeared to contain added substances that enhanced growth. FGD-27 and FGD-28 also appeared to have properties that were detrimental to plant growth when added at high levels, especially FGD27. The detrimental effect of FGD-27 on DM at the highest levels added could have been caused by high $\mathrm{B}$ in the product (Table 1$)^{[38]}$ and high soil $\mathrm{pH}$ disorders.

Plant species differed in response to each of the FGDs added to this acidic soil. Legumes and cool-season grasses received the greatest enhancement of growth from added FGDs, while enhanced growth of warm-season grasses was relatively small. Many warm-season grasses are considered to be relatively tolerant to soil acidity. ${ }^{[29,30]}$ Differences in responses among maize, soybean, cotton, and radish were reported when these plants were grown in acidic soil $\left(\mathrm{pH}_{\mathrm{Ca}} 4.9\right)$ amended with various levels of a FGD in the field. ${ }^{[19]}$ Plants grown in our study had larger differences for root compared to shoot mass, and this was reflected in differences in shoot/root DM ratios. Alfalfa, 
orchardgrass, and tall fescue had higher root than shoot DM and white clover, switchgrass, and eastern gamagrass had higher shoot than root DM.

Even though total RL changes were similar to root DM changes, SRL values (measure of root fineness) were generally lower for plants grown with added $\mathrm{CaCO}_{3}, \mathrm{CaSO}_{4}$, and FGDs than with $\mathrm{CaSO}_{3}$ and in unamended soil. Plants grown under relatively good growing conditions generally have larger root diameters (lower SRL values) compared to smaller root diameters (higher SRL values) for plants grown under low nutrient conditions. ${ }^{[39]}$ Changes in root diameters might be explained in terms of mineral mobility and of soil volumes roots need to exploit, as evidenced by coarse roots being typical of nutrient-rich soils. ${ }^{[39]}$ In addition, $\mathrm{Ca}$ and $\mathrm{K}$ deficient roots were generally shorter and denser and had reduced root mass and length than roots adequately supplied with these minerals. ${ }^{[40]}$ The higher soil $\mathrm{pH}$ from added $\mathrm{CaCO}_{3}$, FGD22, and FGD-27 enhanced white clover root ability to form nodules, which should enhance $\mathrm{N}_{2}$ fixation and improve nutrition of legumes. Even with the fairly good growth that plants made when grown with FGD-28 and high $\mathrm{CaSO}_{4}$, nodules did not readily form on roots of these plants.

The FGDs used in our study benefited growth of forage plants grown in acidic soil, indicating that FGDs could be used effectively for growth enhancement of many plants. Concern might occur when using FGD gypsums at low levels, which may induce Al toxicity and/or Mg deficiency, as well as using too high levels of stabilized and FGD gypsums containing added substances like $\mathrm{Mg}(\mathrm{OH})_{2}$ and $\mathrm{B}$, which could raise soil $\mathrm{pH}$ to excessive values and/or induce $\mathrm{B}$ toxicity. In addition, FGDs containing $\mathrm{S}-\mathrm{SO}_{3}$ should not be used until $\mathrm{S}-\mathrm{SO}_{3}$ has been converted to $\mathrm{S}-\mathrm{SO}_{4}$.

\section{ACKNOWLEDGMENTS}

We thank Ms. S. K. Zeto for technical assistance and Dr. K.D. Ritchey for helps in manuscript review and preparation. Research reported in this paper was carried out at USDA-ARS-AFSRC, Beaver, WV 25813.

\section{REFERENCES}

1. ACAA, Coal Combustion Product (CCP) Production and Use (Surveys); American Coal Ash Association: Alexandria, VA, 1999. 
2. Alcordo, I.S.; Rechcigl, J.E. Phosphogypsum and other by-product gypsums. In Soil Amendments and Environmental Quality; Rechcigl, J.E., Ed.; Lewis Publ.: Boca Raton, FL, 1995; 365-425.

3. Bilski, J.J.; Alva, A.K.; Sajwan, K.S. Fly ash. In Soil Amendments and Environmental Quality; Rechcigl, J.E., Ed.; Lewis Publ.: Boca Raton, FL, 1995; 327-363.

4. Carlson, C.L.; Adriano, D.C. Environmental impacts of coal combustion residues. J. Environ. Qual. 1993, 22, 227-247.

5. Korcak, R.F. Utilization of coal combustion by-products in agriculture and horticulture. In Agricultural Utilization of Urban and Industrial Byproducts; Karlen, D.L., Wright, R.J., Kemper, W.D., Eds.; Spec. Publ. No. 58; Am. Soc. Agron.: Madison, WI, 1995; 107-130.

6. Korcak, R.F. Agricultural uses of coal combustion byproducts. In Agricultural Uses of Municipal, Animal, and Industrial Byproducts; Wright, R.J., Kemper, W.D., Millner, P.D., Power, J.F., Korcak, R.F., Eds.; Cons. Res. Rep. No. 44; U.S. Dept. Agric., Agric. Res. Serv.: Beltsville, MD, 1998; 103-119.

7. Logan, T.J.; Burnham, J.C. The alkaline stabilization with accelerated drying process (N-Viro): an advanced technology to convert sewage sludge into a soil product. In Agricultural Utilization of Urban and Industrial By-products; Karlen, D.L., Wright, R.J., Kemper, W.D., Eds.; Spec. Publ. No. 58; Am. Soc. Agron.: Madison, WI, 1995; 209-223.

8. Miller, W.P.; Sumner, M.E. Agricultural and industrial uses of byproduct gypsums. In Agricultural Uses of Byproducts and Wastes; Rechcigl, J.E., MacKinnon, H.C., Eds.; Am. Chem. Soc.: Washington, DC, 1997; 226-239.

9. Norton, D.; Shainberg, I.; Cihacek, L.; Edwards, J.H. Erosion and soil chemical properties. In Soil Quality and Soil Erosion; Lal, R., Ed.; CRC Press: Boca Raton, FL, 1999; 39-56.

10. Ritchey, K.D.; Elrashidi, M.A.; Clark, R.B.; Baligar, V.C. Potential for utilizing coal combustion residues in co-utilization products. In Beneficial Co-utilization of Agricultural, Municipal and Industrial Byproducts; Brown, S., Angle, J.S., Jacobs, L., Eds.; Kluwer Acad. Publ.: New York, 1998; 139-147.

11. Shainberg, I.; Sumner, M.E.; Miller, W.P.; Farina, M.P.W.; Pavan, M.A.; Fey, M.V. Use of gypsum on soils: a review. Adv. Soil Sci. 1989, 9, 1-111.

12. Sharpley, A.N.; Daniel, T.; Sims, T.; Lemunyon, J.; Stevens, R.; Parry, R. Agricultural Phosphorus and Eutrophication; U.S. Dept. Agric., Agric. Res. Serv.: Washington, DC, 1999; ARS-149. 
13. Stout, W.L.; Sharpley, A.N.; Pionke, H.B. Reducing soil phosphorus solubility with coal combustion by-products. J. Environ. Qual. 1998, 27, $111-118$.

14. Clark, R.B.; Zeto, S.K.; Ritchey, K.D.; Wendell, R.R.; Baligar, V.C. Coal combustion by-product use on acid soil: effects on maize growth and soil $\mathrm{pH}$ and electrical conductivity. In Agricultural Utilization of Urban and Industrial By-products; Karlen, D.L., Wright, R.J., Kemper, W.D., Eds.; Spec. Publ. No. 58; Am. Soc. Agron.: Madison, WI, 1995; $131-155$.

15. Clark, R.B.; Zeto, S.K.; Ritchey, K.D.; Wendell, R.R.; Baligar, V.C. Effects of coal flue; gas desulfurization combustion by-products and calciumnsulfite, nsulfate, and ncarbonate on maize grown in acid soil. In Plant-Soil Interactions at Low pH: Principles and Management; Date, R.A., Grundon, N.J., Rayment, G.E., Probert, M.E., Eds.; Kluwer Acad. Publ.: New York, 1995; 519-525.

16. Dorsett, D.J.; Nickel, L.; Pennington, H.D.; Calloway, D. Preliminary evaluation of coal generated by-product gypsum as a soil amendment on improved hybrid bermudagrass. Proceedings of 11th Int. Symp. on Use and Management of Coal Combustion Products (CCPs); Electric Power Res. Inst.: Palo Alto, CA, 1995; Vol. 1, 10-1-10-7.

17. Stout, W.L.; Priddy, W.E. Use of flue gas desulfurization (FGD) byproduct gypsum on alfalfa. Commun. Soil Sci. Plant Anal. 1996, 27, 2419-2432.

18. Alva, A.K.; Zhu, B.; Hostler, H.K.; Obreza, T.A. Citrus tree growth and fruit production response to flue-gas desulfurization gypsum amendment in sandy soils. In Biogeochemistry of Trace Elements in Coal and Coal Combustion Byproducts; Sajwan, K.S., Alva, A.K., Keefer, R.F., Eds.; Kluwer Academic/Plenum Publ.: New York, 1999; 293-307.

19. Punshon, T.; Knox, A.S.; Adriano, D.C.; Seaman, J.C.; Weber, J.T. Flue gas desulfurization (FGD) residue: potential applications and environmental issues. In Biogeochemistry of Trace Elements in Coal and Coal Combustion Byproducts; Sajwan, K.S., Alva, A.K., Keefer, R.F., Eds.; Kluwer Acad./Plenum Publ.: New York, 1999; 7-28.

20. Stehouwer, R.C.; Sutton, P.; Dick, W.A. Transport and plant uptake of soil-applied dry flue gas desulfurization by-products. Soil Sci. 1996, 161, 562-574.

21. Stehouwer, R.C.; Dick, W.A.; Sutton, P. Acidic soil amendment with a magnesium-containing fluidized bed combustion by-product. Agron. J. 1999, 91, 24-32.

22. Snedecor, G.R.; Cochran, W.G. Statistical Methods; Iowa College Press: Ames, IA, 1957. 
23. Weast, R.C., Ed. CRC Handbook of Chemistry and Physics; CRC Press: Boca Raton, FL, 1978; B-105.

24. Ritchey, K.D.; Kinraide, T.B.; Wendell, R.R. Interactions of calcium sulfite with soils and plants. Plant Soil 1995, 173, 329-335.

25. Wedzicha, B.L. Chemistry of Sulfur Dioxide in Foods; Elsevier Appl. Sci. Publ.: Amsterdam, 1984.

26. Marschner, H. Mineral Nutrition of Higher Plants; Academic Press: San Diego, CA, 1995.

27. Maas, E.V. Crop salt tolerance. In Agricultural Salinity Assessment and Management; Tanji, K.K., Ed.; Manuals and Reports on Engineering Practice No. 71; Am. Soc. Civil Engin.: New York, 1990; 262-304.

28. Bertelsen, F.; Gissel-Nielsen, G. Toxicity of root-applied sulphite in Zea mays. Environ. Geochem. Health 1987, 9, 12-16.

29. Barnes, R.F.; Miller, D.A.; Nelson, C.J., Eds. Forages: An Introduction to Grassland Agriculture; Iowa State Univ. Press: Ames, IA, 1995; Vol. 1.

30. Heath, M.E.; Metcalfe, D.S.; Barnes, R.F., Eds. Forages: The Science of Grassland Agriculture, 3rd Ed.; Iowa State Univ. Press: Ames, IA, 1973.

31. Foy, C.D. Soil chemical factors limiting plant root growth. Adv. Soil Sci. 1992, 19, 87-149.

32. Grove, J.H.; Sumner, M.E. Lime induced magnesium stress in corn: impact on magnesium and phosphorus availability. Soil Sci. Soc. Am. J. 1985, 49, 1192-1196.

33. Sumner, M.E.; Farina, M.P.W.; Hurst, V.J. Magnesium fixation: a possible cause of negative yield responses to lime applications. Commun. Soil Sci. Plant Anal. 1978, 9, 995-1007.

34. Clark, R.B.; Zeto, S.K.; Ritchey, K.D.; Baligar, V.C. Mineral acquisition by maize grown in acidic soil amended with coal combustion products. Commun. Soil Sci. Plant Anal. 2001, 32, 1861-1884.

35. Bertelsen, F.; Gissel-Nielsen, G. Oxidation of sulphite originating from flue gas desulfurization waste in soil. Environ. Geochem. Health 1988, 10, 26-30.

36. Clark, R.B.; Zeto, S.K.; Ritchey, K.D.; Baligar, V.C. Maize growth and mineral acquisition on acid soil amended with flue gas desulfurization by-products and magnesium. Commun. Soil Sci. Plant Anal. 1997, 28, 1441-1459.

37. Clark, R.B.; Baligar, V.C. Acidic and alkaline soil constraints on plant mineral nutrition. In Plant-Environment Interactions, 2nd Ed.; Wilkinson, R.E., Ed.; Marcel Dekker, Inc.: New York, 2000; 133-177. 
38. Clark, R.B.; Zeto, S.K.; Ritchey, K.D.; Baligar, V.C. Boron accumulation by maize grown in acidic soil amended with coal combustion products. Fuel 1999, 78, 179-185.

39. Fitter, A. Characteristics and functions of root systems. In Plant Roots: The Hidden Half, 2nd Ed.; Waisel, Y., Eshel, A., Kafkafi, U., Eds.; Marcel Dekker, Inc.: New York, 1996; 1-20.

40. Baligar, V.C.; Fageria, N.K.; Elrashidi, M.A. Toxicity and nutrient constraints on root growth. HortScience 1998, 33, 960-965. 